\title{
Biodiversity of Social Wasps (Hymenoptera: Vespidae) at Altitudes Above 1600 Meters in the Parque Estadual da Serra do Papagaio, State of Minas Gerais, Brazil
}

\author{
Marcos Magalhães de Souza1, Heloina Nathalliê Mariano da Silva1 ${ }^{1}$, João Batista Dallo, Lizandra de Fátima \\ Martins ${ }^{1}$, Lucas Rocha Milani ${ }^{1} \&$ Mateus Aparecido Clemente ${ }^{2} \bowtie$
}

1. Instituto Federal de Educação, Ciência e Tecnologia do Sul de Minas, Campus Inconfidentes Inconfidentes, Minas Gerais, Brazil, e-mail: marcos.souza@ifsuldeminas.edu.br, heloinanatalie@hotmail.com, joao.b.dallo@hotmail.com, lizandrafmartins@gmail.com, lucasdocero@hotmail.com. 2. Universidade Estadual Paulista - Departamento de Zoologia - Instituto de Biociências- Rio Claro, e-mail: mateus1981@gmail.com (Autor para correspondência ${ }^{\bowtie}$ ).

\section{EntomoBrasilis 8 (3): 174-179 (2015)}

Abstract. The Parque Estadual da Serra do Papagaio is the largest area of natural preservation in the south of Minas Gerais, with areas of Floresta Atlantica, Floresta de Araucaria and Campos de Altitude. Although this is an area of biological importance, there are many groups that have not yet been studied there: for example social wasps, which are insects belonging to order Hymenoptera, family Vespidae, which play an important ecological role in different ecosystems. This study was carried out in the aforementioned natural preservation area at altitudes between 1600 and $2200 \mathrm{~m}$ in 20 days of sampling between July of 2013 and April of 2014, using active searches and attractive traps to record species. Twenty two species of social wasps were sampled, distributed in seven genera. This number is small compared to counts from other studies in this state, which is probably due to the high altitude of this area. There was a predominance of nests with protective casings in the most common species recorded, and the most populous species was Polybia fastidiosuscula Saussure, a finding that can be explained by the superior thermoregulation afforded by the nest casing. Two other common species were Mischocyttarus drewseni Saussure, and Mischocyttarus rotundicolis (Cameron), which have nests without casings; however, these species have dark coloration, as does the substrate used for nesting, and can therefore enhance retention of solar radiation; nevertheless, other biotic and abiotic factors could be involved.

Keywords: Conservation; Fields of Altitude; Independent Foundation; Nesting in Dark; Swarm-founding.

\section{Biodiversidade de Vespas Sociais (Hymenoptera: Vespidae) em Áreas de Altitude Acima de 1600 Metros do Parque Estadual da Serra do Papagaio, Estado de Minas Gerais, Brasil}

Resumo. O Parque Estadual da Serra do Papagaio é a maior Unidade de Conservação do sul de Minas Gerais, com áreas de Mata Atlântica, floresta de Araucária e Campos de Altitude. Apesar da importância biológica da área, muitos grupos animais não foram estudados, como as vespas sociais, insetos que pertencem à ordem Hymenoptera, família Vespidae, e que desempenham importante papel ecológico em diferentes ecossistemas. O estudo foi conduzido nessa Unidade de Conservação em altitudes entre 1600 a $2200 \mathrm{~m}$, no período de julho de 2013 a abril de 2014, durante vinte dias de amostragem, utilizando busca ativa e armadilhas atrativas para registro das espécies. Foram amostradas 22 espécies de vespas sociais distribuídas em sete gêneros. Número menor em relação a outros estudos do estado, o que, provavelmente, foi ocasionado pela elevada altitude. Houve uma predominância de ninhos com invólucro protetor e a espécie mais frequente foi Polybia fastidiosuscula Saussure, o que pode ser explicado pela melhor regulação térmica obtida pelo invólucro. Outras duas espécies frequentes foram Mischocyttarus drewseni Saussure e Mischocyttarus rotundicolis (Cameron) que possuem ninhos sem invólucro, porém essas espécies possuem coloração escura, assim como o substrato utilizado para nidificação e isso poderia reter melhor a radiação solar. Contudo outros fatores bióticos e abióticos podem estar envolvidos.

Palavras-chave: Campos de altitude; Conservação; Fundação enxameante; Fundação independente; Ninhos escuros.

$\sqrt{n}$ There are studies describing the richness, variation and abundance of different insect groups along elevation gradients (JANZEN 1973; FERNANDES \& LARA 1993; HENRIQUESOliveira \& NesSimian 2010).

The general pattern observed is the decline of species richness due to the increase in altitude. According to Lawton et al. (1987), the decline of species richness with increase in altitude is caused by the increase of climate severity, the reduction of habitable areas, and the reduction of diversity of resources and primary productivity. Adaptive factors related to food resources for life strategy are of crucial relevance (FERNANDEs \& PRICE 1991), however, data for social wasps are scarce (KUMAR et al. 2009).

These insects belong to the order Hymenoptera, family Vespidae, and they play various ecological roles, acting as predators of pest crops such as coffee (Coffea arabica L.) and Surinam cherry (Eugenia uniflora L.) (SouzA et al. 2013), and they are frequent visitors of various angiosperms (Clemente et al. 2012) and pollinators of some families (GRANJA \& BARROS 1998).

Despite their importance and the growing of the number of diversity studies in Brazil, especially in the state of Minas Gerais (SouZa \& ZANUNCIO 2012), there are no data available about the distribution and occurrence of social wasps in ecosystems above $1,600 \mathrm{~m}$ of altitude, which are located in the south of the state, particularly in areas of altitude fields.

These altitude fields are characterized by mountain tops more than $1,500 \mathrm{~m}$ high which arose mainly in the Tertiary Period in Serra da Mantiqueira and Serra do Mar, and are associated with igneous and metamorphic rocks. They have very diverse herbaceous flora, including endemic species, which have remarkable similarity to the vegetation of the Patagonian Andes and the southern regions of Brazil (SAFFORD 1999, 2007; VASCONCELOS 2011). 
The aim of this study was to assess the diversity of social wasps in altitude fields above $1,600 \mathrm{~m}$ in elevation, and to assess the ecosystems associated with the south of Minas Gerais in the southeast of Brazil.

\section{MATERIAL AND METHODS}

The present study was conducted in Parque Estadual da Serra do Papagaio $\left(22^{\circ} 12^{\prime} 18.22^{\prime \prime S ~ e ~} 44^{\circ} 47^{\prime} 11.30^{\prime \prime} \mathrm{W}\right)$, which is the largest area of natural preservation in the south of Minas Gerais, with a total area of 22,917 ha, characterized by a tropical climate of high considered conservation-priority in the state (DRUMOND et al. 2005). It is located in the ecological corridor of Serra da Mantiqueira complex, via which it connects geographically with the northern part of Parque Nacional de Itatiaia (IEF 2014).

The park covers the municipalities of Aiuruoca, Alagoa, Baependi, Itamonte and Pouso Alto with altitude between 1,600 and 2,200 $\mathrm{m}$. It has sections of altitude fields with herbaceous vegetation, Araucaria Forest and Mata Atlantic (IEF 2014).

Sampling was conducted over 20 days, covering about $15 \%$ of the park area (Figure 1), during five consecutive days per season each year - winter, spring, summer, and autumn (July and October 2013, and January and April 2014).

The collecting methods used to survey these social wasp species were active searching and the use of attractive traps (SouzA \& Prezoto 2006). Active searching consists of walking on preexisting tracks in the field, without marking fixed points, recording "ad libitum", in other words, all occurrences were registered over the span of the area, in the period from 8:00 AM to 4:00 PM, with surveys in termite mounds, cliffs, rocky outcrops, abaxial surfaces of rigid sheets, in pools formed by the arrangement of bromeliad leaves, on tree trunks, in epiphytes and man-made buildings.

The attractive traps were made with plastic bottles, such as the two-liter translucent "PET" variety, with a triangular lateral opening ( $2 \times 2 \times 2 \mathrm{~cm})$, using baits of guava, passion fruit and sardines (Souza \& Prezoto 2006). In each collection period, five sets were distributed with the three baits (guava, passion fruit and sardines), totalling 15 bottles (distance of $500 \mathrm{~m}$ ) per period, and remained in the field for five days, fixed in the vegetation at an average height of one and a half metres above the ground (about $5 \mathrm{ft}$ ).

To assess the similarity level of the social wasp fauna of this study with those of other studies carried out in the state of Minas Gerais, the Sorensen index was used: $(\mathrm{S})=2 \mathrm{C} / \mathrm{A}+\mathrm{B}$, where $\mathrm{A}$ is the number of species in the study area, B is another study area, and $\mathrm{C}$ is the number of species which are common in both areas compared.

Estimates of biodiversity Jackknife 01 and 02 and species richness were used (cole), and were calculated by the program EstimateS (COLWELL 2013).

Were realized comparison of species of social wasps collected in different altitudes (meters) in the state of Minas Gerais. Area 01 (Parque Estadual da Serra do Papagaio), Area 02 [Parque Estadual do Rio Doce, (SouzA et al. 2012)], Area 03 (City of Uberlândia, Elpino-Campos et al., 2007), Area 04 [City of Barroso, (SouzA \& Prezoto 2006)] and Area 05 [City of Tiradentes, (Souza et al. 2010)] (Figure 1).

The specimens were deposited in the collection of social wasps of IFSULDEMINAS, Inconfidentes campus, and in the Emílio Goeldi Museum, Belém, Pará.

\section{RESULTS AND DISCUSSION}

Twenty-two species belonging to seven genera, and 47 colonies were registered (Table 1). Polybia was the genus with the largest number of species $(\mathrm{n}=10)$, and was also the most frequently collected, being registered in all collects.

The most frequently collected species was Polybia fastidiosuscula Saussure, which was found in $85 \%$ of the collections, followed by Polybia sericea (Olivier) and Mischocyttarus drewseni

Saussure with 65\%, Protonectarina sylveirae (Saussure) and Mischocyttarus rotundicollis (Cameron) with 55\%, Polistes cinerascens Saussure with 50\%, and the other species presented low collecting frequency below of $49 \%$ (Table 1). In other studies

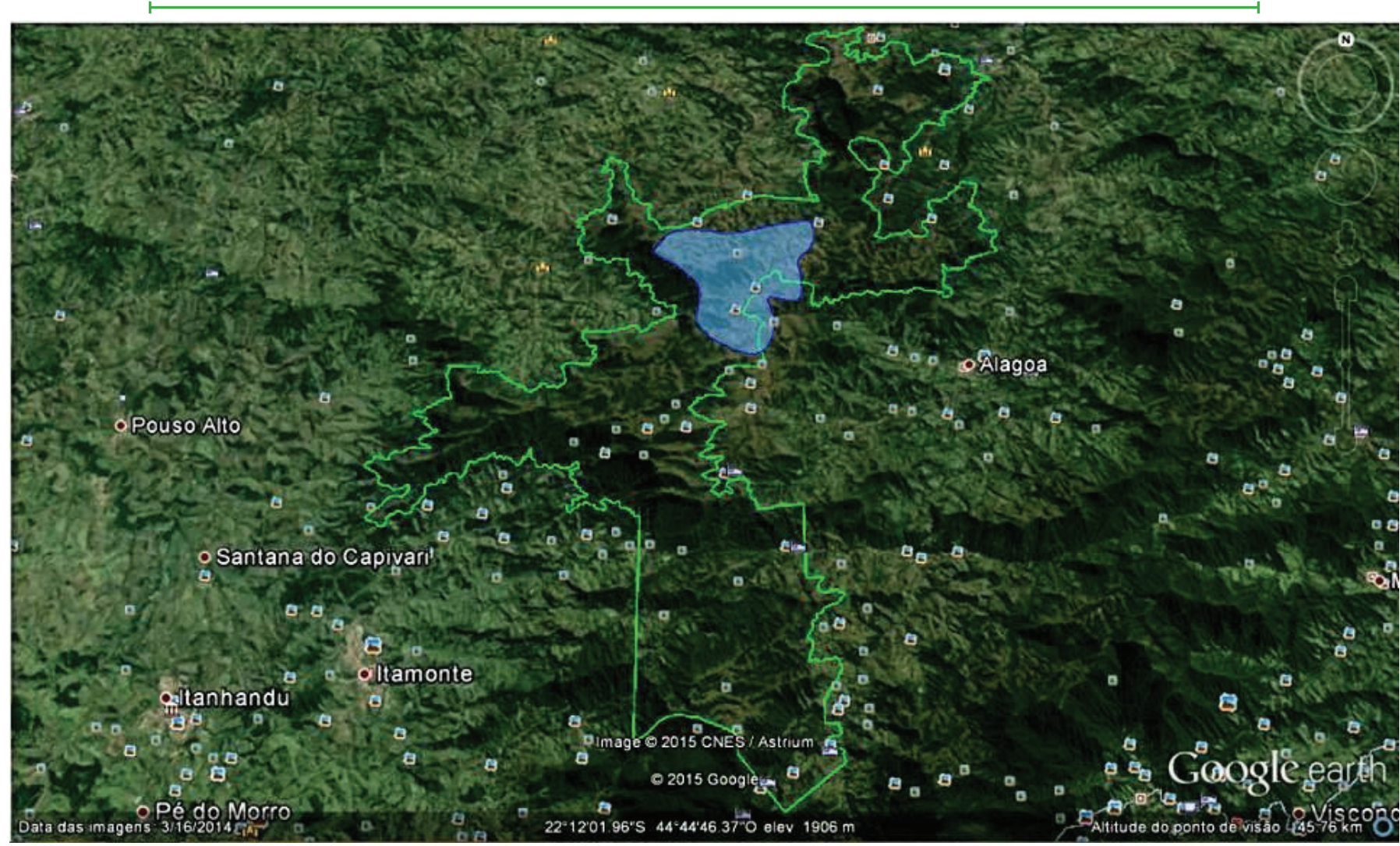

Figure 1. Areas sampled for the register of social wasps in the Parque Estadual Serra do Papagaio, south of the state of Minas Gerais 
Table 1. Species of social wasps collected in different altitudes ( meters) in the state of Minas Gerais. Area 01 (Parque Estadual da Serra do Papagaio), Area 02 [Parque Estadual do Rio Doce (Souza et al. 2012)], Area 03 [City of Uberlândia (Elpino-Campos et al. 2007)], Area 04 [City of Barroso (SouzA \& Prezoto 2006)], Area 05 [City of Tiradentes (SouzA et al. 2010)]. ( - absence of species; + presence of species).

\begin{tabular}{|c|c|c|c|c|c|}
\hline \multirow{3}{*}{ Species } & \multicolumn{5}{|c|}{ Places of Collection } \\
\hline & Area 01 & Area 02 & Area 03 & Area 04 & Area 05 \\
\hline & Above $1,600 \mathrm{~m}$ & 200-500 m & $\begin{array}{c}\text { Around of de } \\
840 \mathrm{~m} \\
\end{array}$ & 900-1,100 m & 950 a $1,200 \mathrm{~m}$ \\
\hline Agelaia pallipes (Olivier) & - & - & + & - & - \\
\hline Agelaia multipicta (Saussure) & + & - & - & + & + \\
\hline Agelaia angulata (Fabricius) & - & + & - & + & - \\
\hline Agelaia centralis (Cameron) & - & + & - & - & - \\
\hline Brachygastra augusti (Saussure) & - & + & - & + & - \\
\hline Brachygastra lecheguana (Latreille) & + & + & + & + & - \\
\hline Clypearia angustior Ducke & - & + & - & + & - \\
\hline Chartergellus communis Richards & - & - & + & - & - \\
\hline Epipona tatua (Cuvier) & - & + & - & - & - \\
\hline Metapolybia cingulata (Fabricius) & - & + & - & - & - \\
\hline Mischocyttarus cerbeus styx (Richards) & - & - & + & - & - \\
\hline Mischocyttarus confusus Zikán & - & - & - & + & + \\
\hline Mischocyttarus drewseni Saussure & + & + & + & + & + \\
\hline Mischocyttarus flavosculetatus Zikán, & - & + & - & - & . \\
\hline Mischocyttarus frontalis (Fox) & - & + & - & - & - \\
\hline Mischocyttarus fluminisensis Zikán & - & + & - & - & - \\
\hline Mischocyttarus latior (Fox) & - & - & + & - & + \\
\hline Mischocyttarus mirificus Zikán & - & - & - & - & + \\
\hline Mischocyttarus punctatus (Ducke) & - & + & - & - & - \\
\hline Mischocyttarus sp. Prox. marginatus (Fox) & - & - & + & - & - \\
\hline Mischocyttarus rotundicolis (Cameron) & + & + & - & + & + \\
\hline Mischocyttarus tricolor Richards & - & - & - & + & - \\
\hline Mischocyttarus wagneri (du Buysson) & - & + & - & + & + \\
\hline Polistes pacificus Fabricius & - & - & - & + & - \\
\hline Polistes simillimus Zikán & + & - & + & + & + \\
\hline Polistes subsericeus Saussure & - & - & + & + & + \\
\hline Polistes versicolor (Olivier) & - & + & + & - & + \\
\hline Polybia bifasciata Saussure & - & + & - & + & - \\
\hline Polybia chrysothorax (Lechtenstein) & + & + & - & + & + \\
\hline Polybia dimidiate (Olivier) & - & + & - & - & - \\
\hline Polybia fastitiosuscula Saussure & + & - & - & + & + \\
\hline Polybia jurinei Saussure & - & + & + & + & + \\
\hline Polybia ignobilis (Haliday) & + & + & + & + & + \\
\hline Polybia minarun Ducke & + & - & - & + & - \\
\hline Polybia occidentalis (Olivier) & + & + & + & + & + \\
\hline Polybia paulista $\mathrm{H}$. von Ihering & + & - & + & + & + \\
\hline Polybia platycephala Richards & + & + & + & + & + \\
\hline Polybia punctata du Buysson & + & - & - & - & - \\
\hline Polybia rejecta (Fabricius) & - & + & - & - & - \\
\hline Polybia ruficeps Richards & - & - & + & - & - \\
\hline Polybia sericea (Olivier) & + & + & + & + & + \\
\hline Polybia scutelaris (White) & + & - & + & + & + \\
\hline Polybia striata (Fabricius) & - & + & + & - & - \\
\hline Polybia signata Ducke & - & + & - & - & - \\
\hline Protopolybia sedula (Saussure) & + & - & - & + & + \\
\hline Protonectarina sylveirae (Saussure) & + & - & - & + & + \\
\hline Parachartegus fraternus (Griboldo) & - & - & - & - & + \\
\hline Parachartegus pseudapicalis Willinck & - & - & + & - & - \\
\hline Pseudopolybia vespiceps (Saussure) & - & - & + & + & + \\
\hline
\end{tabular}


T carried out in Minas Gerais (Souza \& Prezoto 2006; ElpinoCAmpos et al. 2007; Souza et al. 2010, 2012), the species $P$. fastidiosuscula and $P$. sylveirae were registered in the city of Barroso (Souza \& PrEzoto 2006) and the city of Tiradentes (SouzA et al. 2010), at altitudes from 900 to 1,100 metres and 950 to $1,200 \mathrm{~m}$, respectively, but they were not registered in places at lower elevation such as the city of Uberlândia, which is about 800 $\mathrm{m}$ high (Elpino-CAmpos et al. 2007), or the Parque Estadual do Rio Doce, with an elevation of 200 to 500 m (SouzA et al. 2012). These data may indicate an adaptation of both species to altitudes above $900 \mathrm{~m}$, but may also be due to the geographical proximity of the areas, because the Serra do Papagaio is located far from the city of Barroso and Tiradentes, about $150 \mathrm{~km}$, while the distance between the Parque Estadual do Rio Doce and the city of Uberlândia is around $400 \mathrm{~km}$. The weather could be another relevant variable because the Parque Estadual Serra do Papagaio and the cities of Barroso and Tiradentes are under the influence of a tropical climate.

The other species frequently collected were $P$. sericea, $M$. drewseni, $M$. rotundicolis e $P$. cinerascens, which were found in the other studies analyzed (Souza \& PREzoto 2006; ElPINO-CAMPOS et al. 2007; SouzA et al. 2010) (Table 1). According to Sorensen's similarity calculating the fauna and the social wasps of the Parque Estadual Serra do Papagaio there is a great similarity with the city of Barroso, 0.66 , with 20 common species, followed by the studies in the city of Tiradentes, with 17 common species; while the level of similarity with the species of the city of Uberlândia, $840 \mathrm{~m}$ in altitude, was 0.43 having 11 species in common, and with the Parque Estadual do Rio Doce, 200 to $500 \mathrm{~m}$ in altitude, was of 0.26 , with eight species in common, data that reinforce the discussion above. Another relevant comparison was carried out through the information of the naturalist Joseph Francisco Zikán; according to (ZIKÁN 1949), the naturalist described 30 species of social wasps in the Parque Nacional do Itatiaia (Table 2); however, even though it forms a complex with the Parque Estadual do Papagaio, none of these species were registered in this study. This can be explained by the fact that the observations made by Zikán were made at altitudes of 700-1100 m. (ZiKán 1949), while the present study collected at altitudes up to 1,600 m.

However, five species collected in Itatiaia (Zikán 1949), Mischocyttarus confusus Zikán, Mischocyttarus funerulus Zikán, Mischocyttarus paraguayensis Zikán, Mischocyttarus atramentarius Zikán and Polistes simillimus Zikán were also registered in the city of Barroso, 900-1,100 $\mathrm{m}$ in altitude (SouzA \& PREzoto 2006), including the first three which were new registers in Minas Gerais. Mischocyttarus mirificus Zikán was already found in the city of Tiradentes, 950 to 1,200 m (SouzA et al. 2010). These data, added to what was already mentioned in this study, seem to lead to the conclusion that there are distinct groups of social wasp species at different elevations.

The presence of Polybia and Protonectarina at elevations above $1600 \mathrm{~m}$ could be the result of two factors: the architectural pattern of the nest, which has a protective envelope, and the foundation of nests by swarming. The presence of nests with protective envelopes allows better thermal regulation by individuals of the colony, which helps to maintain a temperature favorable for survival (Hozumi et al. 2010). In other social insects of order Hymenoptera, temperatures in nests are not only regulated by the presence of a protective cover, but also by the materials used in their construction, the physical location, and the individuals' metabolic activity (WILSON 1972; ZMITROWICZ 2001). Another aspect that was discussed in an altitudinal study carried out in Central America (Kumar et al. 2009) is the correlation between the colony foundation with elevation in altitudes above 1,600 , demonstrating that in higher altitudes there is a predominance of species with foundation by swarming. JEANNE (1991) presents the advantages of this type of foundation compared to independent foundation wasps, in which the swarming model queen mortality is reduced, and queens are better protected within the colony which provides housing; it allows for establishment of more colonies; the swarm founding model usually involves multiple queens, and the rates of egg-laying and colony growth are high in comparison with species of independent foundation (WENZEL 1991; SмIтн et al. 2001).

The genera Mischocyttarus and Polistes, with four and three species respectively (Table 1), were also common in areas above $1800 \mathrm{~m}$, even existing nests of the stelocyttarous gymnodomous type without protective envelopes (RICHARDS \& RICHARDS 1951) and formation of colonies way independent foundation, which seems to be disadvantageous for the colony survival in winter at this high altitude; however some of these species had dark coloration, and those who had lighter color, with yellow areas on the mesossomo and abdomen, such as $P$. cinerascens, nested in areas with dark substrate, as hillside with dense herbaceous vegetation. This dark coloration on the insect's body can increase the absorption of solar radiation, which can help in physiological adaptation to low temperatures and the absence of the sun (O'DONNELL 2000).

In social wasps with lighter coloration, such as yellow, the presence of dark bands along the body, as seen in $P$. cinerascens and Polistes bilardieri (Fabricius), could be capable of absorbing heat, which occurs in a few species of Lepidoptera with dark bands on the wings (BERTHIER 2005). Studies with locusts have demonstrated that variations in body temperature occur due to coloration, but they are influenced by wind speed; however, empirical studies have described very different patterns (UMBERs et al. 2013). The difference in temperature reported for insects from different taxa varying in color may range from no $\left(\mathrm{O}^{\circ} \mathrm{C}\right)$ to substantial (up to $12^{\circ} \mathrm{C}$ ) effect on body temperature, which suggests that not only abiotic factors would explain the presence of some kinds of social wasps above $1,600 \mathrm{~m}$, but also physiological factors. Nesting in dark substrate also helps increase retention of solar radiation, and the presence of vegetation also accomplishes this effect. Soil with dark vegetation retains more heat and this could be used by the insect, as has already been evidenced by the behavior of other insect groups, moving to the ground with the purpose of regulating body temperature (MAY 1979).

Table 2. Species of social wasps collected and described for the Parque Nacional de Itatiaia (MG, RJ) by the naturalist Joseph Franciscl Zikán (Richards 1978) and for the city of Barroso ( MG) (SouZA \& Prezoto 2006). ( - absence of species; + presence of species).

\section{Species collected and described in the Parque Nacional do Itatiaia MG, RJ \\ Species present in the city of Barroso, MG}

Mischocyttarus atramentarius Zikán

\section{Mischocyttarus alternatus Richards}

Mischocyttarus araujoi Zikán

Mischocyttarus adjectus Zikán

Mischocyttarus cabauna Zikán

Mischocyttarus confirmatus Zikán

Mischocyttarus confusus Zikán

N Mischocyttarus confusoides Zikán

Mischocyttarus costalimai Zikán

Mischocyttarus clypeatus Zikán

Mischocyttarus crypticus Zikán 
Table 2. continued...

Species collected and described in the Parque Nacional do

Itatiaia MG, RJ

Species present in the city of Barroso, MG

Mischocyttarus cryptobius Zikán

Mischocyttarus cristatus Zikán

Mischocyttarus declaratus Zikán

Mischocyttarus extinctus Zikán

Mischocyttarus flavosculetatus Zikán,

Mischocyttarus funerulus Zikán

Mischocyttarus itatiayaensis Zikán

Mischocyttarus iheringi Zikán

Mischocyttarus interjectus Zikán

Mischocyttarus infrastrigatus Zikán

Mischocyttarus mirificus Zikán

Mischocyttarus mutator Zikán

Mischocyttarus mimicus Zikán

Mischocyttarus parallelogrammus Zikán

Mischocyttarus pedunculatus Zikán

Mischocyttarus similatus Zikán

Mischocyttarus scitulus Zikán

Polistes binotatus Saussure

Polistes simillimus Zikán

\section{ACKNOWLEDGMENTS}

The authors thank the IEF-MG, the staff of the Parque Estadual Serra do Papagaio, the IFSULDEMINAS, Campus Inconfidentes for the operational support. The Dr. Orlando Tobias da Silveira, the museum Emílio Goeldi, the Dr. Abner Elpino-Campos for the statistical analyzes.

\section{REFERENCES}

Berthier, S., 2005. Thermoregulation and spectral selectivity of the tropical butterfly Prepona meander: a remarkable example of temperature auto-regulation. Journal of Applied Physics, A. 80: 1397-1400.

Clemente, M.A., D. Lange, K. Del-Claro, F. Prezoto, N.R. Campos \& B.C. Barbosa, 2012. Flower-Visiting Social Wasps and Plants Interaction: Network Pattern and Environmental Complexity. Psyche, 1-10.

Colwell, R.K., 2013. EstimateS: Statistical estimation of species richness and shared species from samples. Version 9. User's Guide and application: http://purl.oclc.org/estimates. [Accessed in: 09.12.2014].

Drummond, G.M., C.S. Martins, A.B.M. Machado, F.A. Sebaio \& Y. Antonini, 2005. Biodiversidade em Minas Gerais. Um Atlas para sua Conservação. Fundação Biodiversitas, Belo Horizonte, MG., 222 p.

Elpino-Campos A, K. Del-Claro \& F. Prezoto, 2007. Diversity of Social Wasps (Hymenoptera, Vespidae) in cerrado fragments of Uberlândia, Minas Gerais State, Brazil. Neotropical Entomology, 36: 685-692.

Fernandes, G.W. \& A.C.F. Lara, 1993. Diversity of Indonesian gall-forming herbivores along altitudinal gradients. Biodiversity Letters, 1: 186-192.

Fernandes, G.W. \& P.W. Price, 1991. Comparisons of tropical and temperate galling species richness; the roles of environmental harshness and plant nutrient status, p. 91-115. In: Price, P.W., T.M. Lewinsohn, G.W. Fernandes \& W. W. Benson (Eds.) Plant-animal interactions: evolutionary ecology in tropical and temperate regions. New York, John Wiley, XIV, 639 p.

Granja e Barros, M., 1998. Sistemas reprodutivos e polinização em espécies simpátricas de Erythroxylum P. Br. (Erythroxylaceae) do Brasil. Revista Brasileira de Botânica, 21: 159-166.

Henriques-Oliveira, A.L. \& J.L. Nessimian, 2010. Aquatic macroinvertebrate diversity and composition in streams along an altitudinal gradient in Southeastern Brazil. Biota Neotropica, 10: 115-128. <http://dx.doi.org/10.1590/S167606032010000300012> [Accessed in: 11.28.2014].

Hozumi, S., S. Mateus, K. Kudô, T. Kuwahara, S. Yamane \& R.
Zucchi. 2010. Nest Thermoregulation in Polybia scutellaris (White) (Hymenoptera: Vespidae). Neotropical Entomology, 39: 826-828.

IEF, 2014. Parque Estadual da Serra do Papagaio. Disponível em: <http://www.ief.mg.gov.br/areasprotegidas $/ 211$ ?task=view $>$ [Accessed in: 09.02.2014].

Janzen, D.H., 1973. Sweep samples of tropical foliage insects: effects of seasons, vegetation types, elevations, time of day, and insularity. Ecology, 54: 687-708.

Jeanne, R.L., 1991. The swarm founding Polistinae, p. 191-231. In: Ross, K.G. \& R.W. Matthews (Eds.). The social biology of wasps, Cornell University Press, Ithaca, New York, 696 p.

Kumar, A., J.T. Longino, R.K. Colwell \& S. O'Donnell, 2009. Elevational Patterns of Diversity and Abundance of Eusocial Paper Wasps (Vespidae) in Costa Rica. Biotropica 41: 338346.

Lawton, J.H, M. Macoarvin \& P.A. Heads, 1987. Effects of altitude on the abundance and species richness of insect herbivores on bracken. Journal Animal Ecology, 56: 147-160.

May, M.L., 1979. Insect thermoregulation. Annual Review of Entomology 24: 313-349.

O'Donnell, S. 2000. Eusocial wasps (Vespidae: Polistinae), p. 129-131. In: Nadkarni, N.M. \& N.T. Wheelwright (Eds.). Monteverde: Ecology and conservation of a tropical cloud forest. Oxford University Press, Oxford, UK, 573 p.

Richards, O. W., 1978. The social wasps of the Americas, excluding the Vespinae. British Museum (Natural History), London, $580 \mathrm{p}$.

Richards, O.W. \& M.J. Richards, 1951. Observations on the social wasps of South America (Hymenoptera, Vespidae). Transections of the Royal Entomological Society of London, 102: $1-170$.

Safford, H.D., 1999. Brazilian páramos I. An introduction to the physical environment and vegetation of the campos de altitude. Journal of Biogeography, 26: 693-712.

Safford, H.D., 2007. Brazilian páramos IV. Phytogeography of the campos de altitude. Journal of Biogeography, 34: 17011722.

Smith, A.R; S. O’Donnell \& R.L. Jeanne, 2001. Correlated evolution of colony defense and social structure: A comparative analysis in eusocial wasps (Hymenoptera: Vespidae). Evolutionary Ecology Research, 3: 331-344.

Souza, M. M., J.C. Zanuncio, 2012. Marimbondos-Vespas sociais (Hymenoptera: Vespidae). Editora UFV, Viçosa, 79p.

Souza, M. M., P. Pires, M. Ferreira, T.E. Ladeira, M.C. S. Pereira, A. Elpino-Campos \& J.C. Zanuncio, 2012. Biodiversidade de vespas sociais (Hymenoptera: Vespidae) do Parque Estadual do Rio Doce, Minas Gerais, Brasil. MG. Biota, 5: 4-19. 
Souza, M.M. \& F. Prezoto, 2006. Diversity of social wasps (Hymenoptera: Vespidae) in semideciduos Forest and cerrado (savanna) regions in Brazil. Sociobiology 47: 135-147.

Souza, M.M., J. Louzada, J.E. Serrão \& J.C. Zanuncio, 2010. Social wasps (Hymenoptera: Vespidae) as indicators of conservation degree of Riparian Forests in Southeast Brazil. Sociobiology, 56: 387-396.

Souza, G.K., T.G. Pikart, G.C. Jacques, A.A. Castro, M.M. Souza, J.E. Serrao \& J.C. Zanuncio, 2013. Social Wasps on Eugenia uniflora Linnaeus (Myrtaceae) Plants in an Urban Area. Sociobiology, 60: 204-209.

Umbers, K.D.L., M.E. Herberstein \& J.S. Madin, 2013. Colour in insect thermoregulation: empirical and theoretical tests in a colour-changing grasshopper. Journal of Insect Physiology, 59: 81-90.

Vasconcelos, M.F., 2011. O que são campos rupestres e campos de altitude nos topos de montanha do Leste do Brasil? Revista Brasileira de Botânica, 34: 241-246.

Wenzel, J.W., 1991. Evolution of nest architecture in social vespids, p. 480-519. In: Ross, K.G. \& Matthews, R.W. (Eds.). The social biology of wasps. Cornell University Press, Ithaca, New York, 696 p.

Wilson, E.O., 1972. The insect societies. Cambridge, Massachusetts, The Belknap Press of Harvard University, $562 \mathrm{p}$.

Zikán, J.F., 1949. O gênero Mischocyttarus Saussure (Hymenoptera, Vespidae), com a descrição de 82 espécies novas. Boletim do Parque Nacional do Itatiaia, 1: 1-125.

Zmitrowicz, W., 2001. As estruturas territoriais dos insetos. Estudos Avançados, 15: 193-212.

\section{Received in: $03 / 25 / 2015$ \\ Accepted in: $08 / 30 / 205$}

\section{Suggested citation:}

M.M. Souza, H.N.M. Silva, J.B. Dallo, L. de F. Martins, L.R. Milani \& M.A. Clemente, 2015. Biodiversity of Social Wasps (Hymenoptera: Vespidae) at Altitudes Above 1,60o Meters in the Parque Estadual da Serra do Papagaio, State of Minas Gerais, Brazil. EntomoBrasilis, 8 (3): 174-179. Available in: $\underline{\text { doi:10.12741/ebrasilis.v8i3.519 }}$
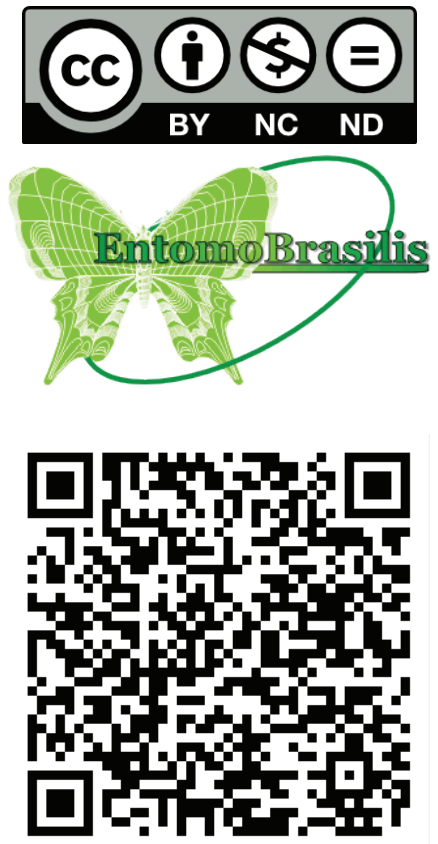